\title{
Consumer Behaviour in Halal Food: A Systematic Mapping Study
}

\author{
Anita Maulina ${ }^{1}$, Nur Fitri Rahmawati ${ }^{2}$, Anisa Arizona ${ }^{3}$ \\ ${ }^{123}$ The STIAMI Institute Social and Management Sciences \\ Correspondent: anitacempaka@gmail.com
}

Submitted : September 25, 2020 Revised : October 17,2020 Published : October 31, 2020

\begin{abstract}
This article is discussing about Consumer Behaviour in Halal Food using a Systematic Mapping Study. The purpose of this mapping study is to find out what topics about Halal food have been researched by scientists around the world. Search was conducted through the research article databases such as Emerald, ScienceDirect, ProQuest and Taylor \& Francis Online. Searches were only carried out on articles published between 2015 - 2020. The inclusion criteria were articles from scientific journals only. The results of this mapping study can be used as a reference for finding new topics in research on Halal Food.
\end{abstract}

Keyword: consumer behaviour, halal food, Systematic Mapping Study.

\section{INTRODUCTION}

Islam is a religion that always follows new era. The world development rapidly forces the entire Muslim population of the world to race as quickly as possible to keep pace with its growth. Currently, the products or services have emerged as a result of the growth of the competitive global market. This must be observed by Muslims everywhere. In order to maintain caution in consuming a product or service, Muslims should have their own way of determining purchasing decisions. Especially in choosing halal food and drinks and how to get them. "It is forbidden for you to (eat) carcasses, blood, pork, (animal meat) that were slaughtered in the name other than Allah, those who were strangled, those who were beaten, those who fell, who were gored, and were killed by wild animals, except those you had slaughtered them, and (forbidden). for you who were slaughtered for idols." (Surah Al Maidah: 3).

Halal means permissible and Haram means forbidden or illegal ((Talib, 2015). According to the Global Islamic Economy Report 2018/2019, the halal food industry dominates the Islamic economic sector. The outlay Muslims around the world is predicted to US \$ 1.9 trillion in 2023, which is a growth of 6.1\% (Dinar Standard, 2018). Halal food is not only for the benefit of Muslims in fulfilling religious requirements but also for safety, quality and integrity (Ab Talib \& Ai Chin, 2018). For the Muslim, a product is considered healthy, safe or hygienic, only if it has gone through the Halal process and is made with halal ingredients in accordance with sharia principles (Ahmed et al., 2019). In fact, in order to increase the number of sales, several fast food restaurants such as McDonald's, KFC, Burger King or Taco Bell have participated in enlivening the global halal market, including in countries with Muslim minorities (Martin, 1971). Giant retailers such as Carrefour and Albert Heijn have also introduced Halal meat in their product range (Awan, 2015).

The halal food industry is a very developed industry. Non-Muslims have started to consider the halalness of consuming the product. This is due to four themes that have emerged that affect non-Muslim perceptions of Halal, namely acculturation, knowledge of Halal, animal welfare issues and the quality of Halal products (Ayyub, 2015). In the global food and beverage industry, halal 
means pure food, does not contain pork or animals that are prohibited in Islam for consumption and are not touched by pork residues or forbidden liquids (alcohol, blood, feces) (Fischer, 2012).

This study provides an overview the current literature related to consumer behavior in consuming halal food or drinks. The Systematic Mapping Study was conducted because it used less effort than the Literature Review study (Heredia et al., 2015). Therefore this study was conducted with the hope that it can help further research (Fauzi et al., 2019) regarding Halal Food from a consumer's point of view, namely purchase intention or behavior (Marmaya et al., 2019), purchasing decisions (Muslichah et al., 2019) ), purchasing perceptions (Rahman et al., 2018), willingness to pay (Ahmed et al., 2019), consumer awareness (Bashir, 2019), consumer trust (Khan \& Khan, 2019), and consumer value (Mahbubi et al., 2019).

The data search was carried out using databases from Emerald, ScienceDirect, ProQuest and Taylor \& Francis Online and produced 33 articles that match the topics of interest (Kitchenham, 2004). From the analysis of the 33 articles, the Research Question (RQ) can be described, such as:

1. What is the focus and locus of research on Consumer Behavior in Halal Food during the last 5 years?

2. What methodology and types of paper are generally used in research on Consumer Behavior in Halal Food?

3. What is the trend in the publication of countries in the world regarding Consumer Behavior in Halal Food from time to time?

The results of this study provide a comprehensive understanding of Consumer Behavior in Halal Food and are useful for future research related to Halal Food.

\section{METHODS}

This research is entirely a secondary study using a Systematic Mapping Study (SMS) which comes from a systematic literature review search or commonly called a Systematic Literature review (SLR). This method is often used in research in the health sector (Petersen et al., 2008) but not widely used in research on Halal Food. Systematic literature review meant is a way of identifying, evaluating and interpreting all available research that is relevant to a particular research question, or topic area, or phenomenon of interest. Individual studies that contribute to a systematic review are called primary studies; Systematic review is a form of secondary study (Kitchenham, 2004).

In general, the SLR method is used to summarize empirical evidence, look for gaps in existing research so that they can be used as a reference for future research and also to provide background for future research (Kitchenham, 2004). Systematic mapping studies are carried out by giving special categories to areas of interest so that they can provide an overview of visual summaries, maps and research results (Petersen et al., 2008). In summary, this SMS describes the types of activities that have been carried out in areas of interest (Fauzi et al., 2019).

The Research Question (RQ) on SMS is much broader than the SLR (Kitchenham, 2004). The research question is based on the results of categorizing research topics, namely the Consumer Behavior in countries in the world related to Halal Food.

The first step in this research is selecting data sources, searching using strings, then determining inclusion and exclusion criteria (Fauzi et al., 2019). This study took the process of research searching (Petersen et al., 2008). In the table we describe the Systematic Mapping Study 
Consumer Behaviour in Halal Food: A Systematic Mapping Study

Maulina, Rahmawati, \& Arizona

(SMS) process. The research data was taken from Emerald, ScienceDirect, ProQuest and Taylor \& Francis Online databases for the last 5 years.

Table 1

Data Search Result

\begin{tabular}{llr}
\hline Sources & Intervention Searching & Detected \\
\hline Emerald & Search String “Consumer Behavior" and "Halal Food” & 246 \\
& Research Paper & 168 \\
& Relevant Paper & 21 \\
\hline ScienceDirect & Search String “Consumer Behavior" and "Halal Food” & 42 \\
& Research Paper & 34 \\
& Relevant Paper & 5 \\
\hline ProQuest & Search String “Consumer Behavior" and "Halal Food” & 32 \\
& Research Paper & 17 \\
Taylor \& F Online & Relevant Paper & 1 \\
& Search String “Consumer Behavior" and "Halal Food” & 34 \\
& Research Paper & 32 \\
& Relevant Paper & 6 \\
\hline
\end{tabular}

Source: Data Processed (2020)

We used the search strings "Consumer Behavior" and "Halal Food" to categorize the searches on the electronic databases Emerald, ScienceDirect, ProQuest and Taylor \& Francis Online. From the search, 354 articles were found but only 251 were research papers and only 33 of them were relevant to the interest topic. The next step is to determine inclusion and exclusion criteria. This step provides an exclusion of the article to make the mapping easier (Petersen et al., 2008). We present illustrations to make it easier to understand.

Table 2

Inclusion and Exclusion Criteria

\begin{tabular}{|c|c|}
\hline Inclusion & Exclusion \\
\hline $\begin{array}{l}\text { 1. Articles focus on Consumer Behavior in } \\
\text { Halal Food }\end{array}$ & $\begin{array}{l}\text { 1. Articles that do not examine Consumer } \\
\text { Behavior in Halal Food }\end{array}$ \\
\hline 2. English only & 2. Articles that are not in English \\
\hline 3. Articles are from Journal and conferences & $\begin{array}{l}\text { 3. Articles are from Thesis, Dissertation, Letter, } \\
\text { Review Article, books, report review, or activity } \\
\text { report that are not clear. }\end{array}$ \\
\hline 4. Articles that have been peer reviewed & $\begin{array}{l}\text { 4. Articles that have not been peer reviewed } \\
\text { 5. Duplicate research }\end{array}$ \\
\hline
\end{tabular}

Source: (Banaeianjahromi \& Smolander, 2016)

The classification scheme used in this study adapted from the classification scheme developed by (Petersen et al., 2008). For easy understanding, it is presented in the image below:

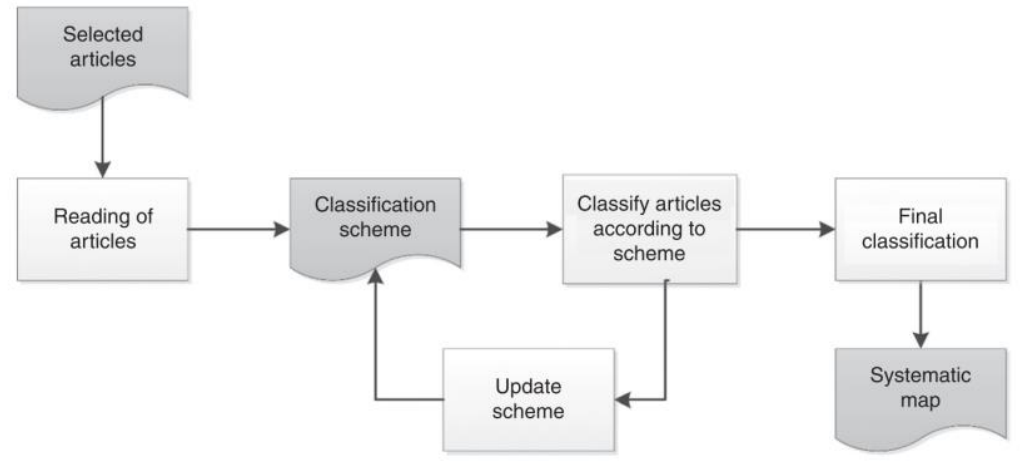

Picture 1 Systematic Mapping Study (SMS) Process

Sumber: (Banaeianjahromi \& Smolander, 2016) 
Consumer Behaviour in Halal Food: A Systematic Mapping Study

Maulina, Rahmawati, \& Arizona

\section{RESULTS AND DISCUSSION}

From the 251 articles that have been collected, there are only 33 articles that fit the topic. This simple grouping only uses the help of Microsoft Excel with the categories Title, Author Name, Year of Publication, Country, Research Focus, Research Locus, Paper Type and Research Method.

The image is presented to facilitate illustration of the focus and locus of this research
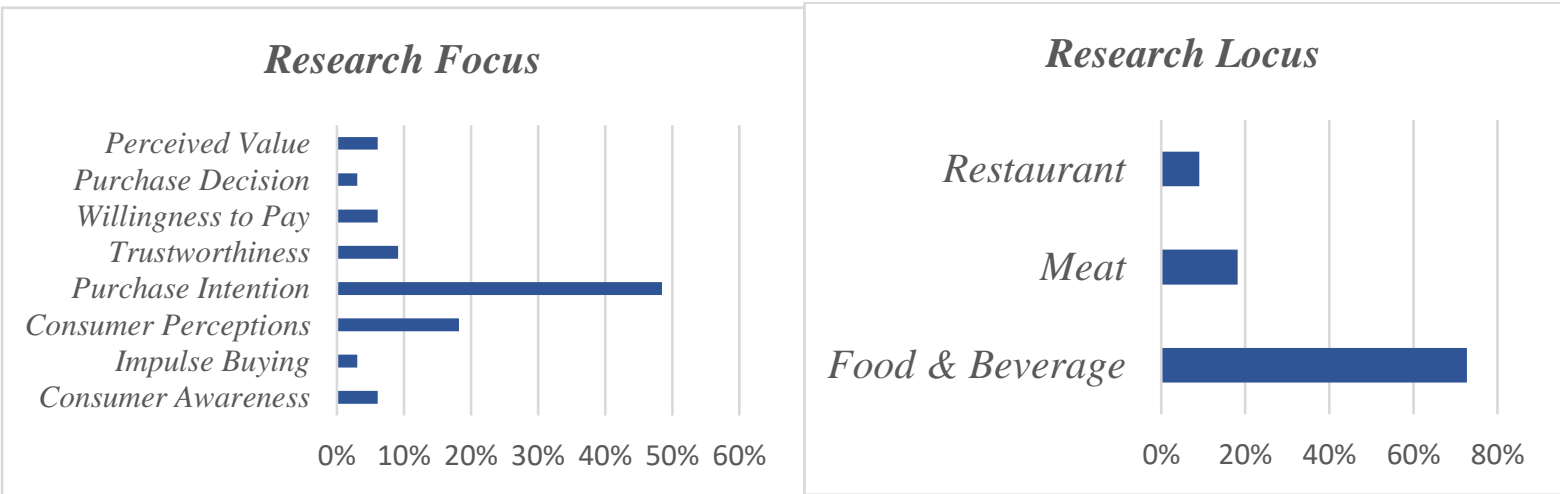

Picture 2 Focus and Locus of Research

Source: Data Processed (2020)

To answer the Research Question (RQ1), we categorized the focus and locus of the study from all 33 relevant articles. A total of 16 research articles (48\%) discussed Purchase Intention, 6 articles (18\%) discussed Consumer Perceptions, 3 articles (9\%) discussed Trustworthiness, 2 articles $(6 \%)$ each discussed Consumer Awareness, Willingness to Pay, Perceived Value and the remaining 1 article $(3 \%)$ each discusses Impulse Buying and Buying Decision. Whereas for the Consumer Behavior in Halal Food research locus, there were 24 articles $(73 \%)$ that examined Food and Beverage, 6 articles $(18 \%)$ on meat or raw meat and the remaining 3 articles $(9 \%)$ on Restaurant.

Table 3

Classification Category

\begin{tabular}{ll}
\hline Paper Type & \\
\hline Validation Research & $\begin{array}{l}\text { The methods being investigated are new and not yet implemented } \\
\text { in practice. } \\
\text { The method under investigation is implemented in practice and } \\
\text { presented in the evaluation of the method. } \\
\text { A solution to a problem is proposed, this solution proposal can be } \\
\text { a new or applied approach and an existing one. } \\
\text { This paper introduces a new perspective of an existing thing using } \\
\text { a taxonomy or conceptual framework. } \\
\text { The author's personal experience of what and how something is } \\
\text { done in practice. }\end{array}$ \\
Experience Paper & $\begin{array}{l}\text { Types of approach fields are ethnographic, fieldwork, soft data, } \\
\text { symbolic interactionism, naturalistic, descriptive, role-involved } \\
\text { observation, phenomenological, documentary data, case studies, } \\
\text { descriptive historical studies, and environmental studies, } \\
\text { observation, document review, participant observers. and story } \\
\text { The types of approaches are experimental, hard data, empirical, } \\
\text { positivistic, real facts in society and statistics, experiments, surveys, } \\
\text { structured interviews, and so on. }\end{array}$ \\
\hline Quantitative &
\end{tabular}




\begin{tabular}{ll}
\hline Research Focus & \\
\hline Perceived Value & $\begin{array}{l}\text { The overall assessment of the usefulness of a product (or service) is } \\
\text { based on perceptions of what is received and what is given } \\
\text { (Zeithaml, 1988) } \\
\text { The desire of consumers to behave in certain ways to own, dispose } \\
\text { of, and use a product or service (Puiu \& Budica, 2016) } \\
\text { Maximum amount of money or effort spent by consumers to own } \\
\text { or consume the product (Wertenbroch \& Skiera, 2002) } \\
\text { Willingness to Pay } \\
\text { Confidence source of information obtained by consumers in } \\
\text { consuming the product (Bonne \& Verbeke, 2008) } \\
\text { Purchase Intention } \\
\text { The willingness of consumers who are conscious about the desire to } \\
\text { buy a product (Diallo, 2012) } \\
\text { A process of how individuals see and understand their environment. } \\
\text { It is about the selection, organization and stimuli interpretation by } \\
\text { individuals (Fill, 2002) } \\
\text { The act of buying without prior consideration or planning before } \\
\text { entering a store (Mowen \& Minor, 2001) } \\
\text { Knowledge or understanding of a particular subject or situation } \\
\text { (Randolph, 2003) }\end{array}$ \\
\hline
\end{tabular}

Source: (Petersen et al., 2008)

The type of research categorized in this study uses research from (Wieringa et al., 2006) which classifies the types of research into 5 types, namely: Validation Research, Evaluation Research, Solution Proposal, Philosophical Paper and Experience Paper. For easy illustration, the image below is presented.

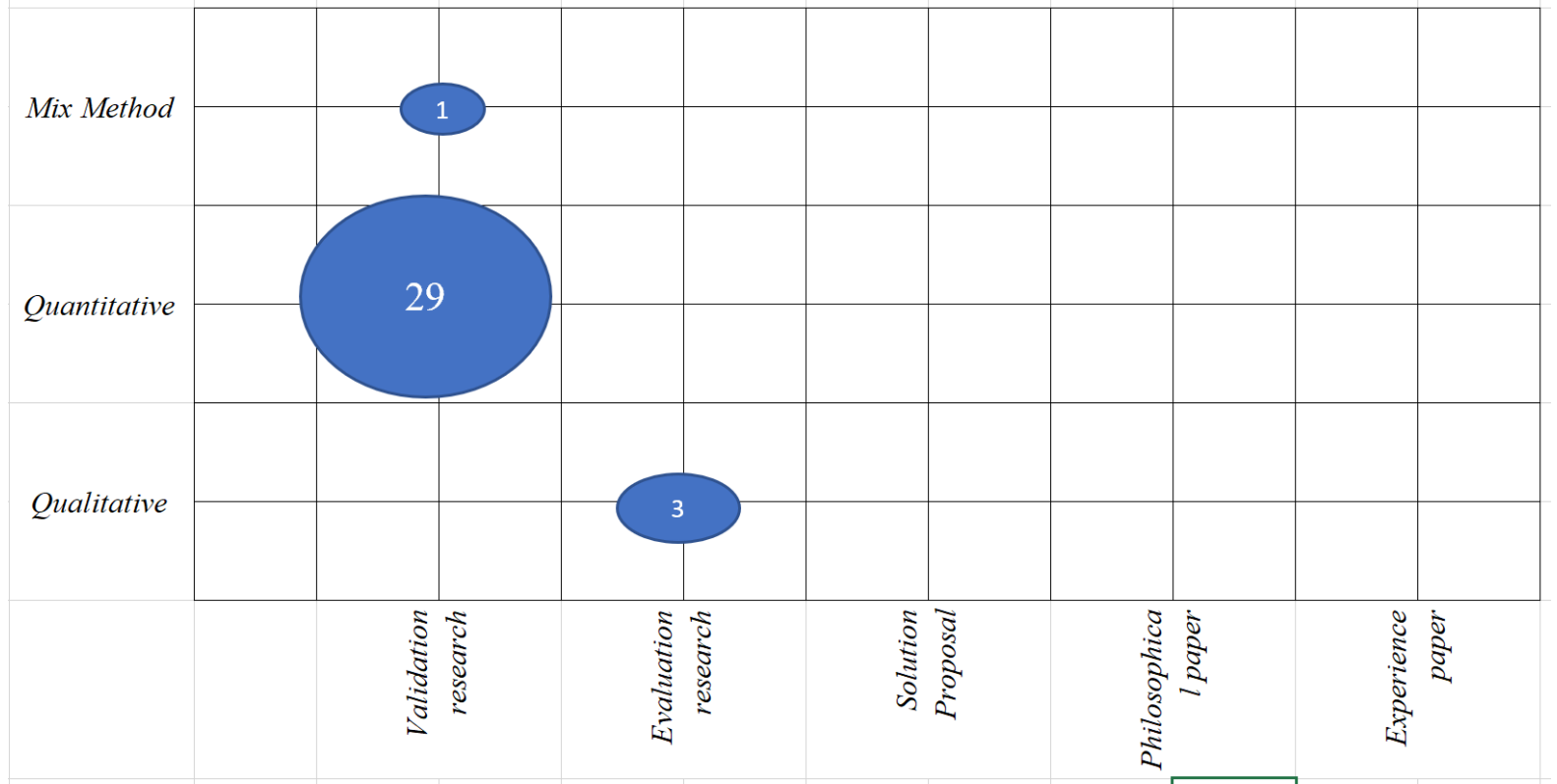

Picture 3 Research Method Distribution Map

To provide RQ2 answer, we categorized the methods and types of research in the Systematic Mapping Study using (Wieringa et al., 2006). From the picture above shows as many as 30 articles or $90 \%$ are a type of Validation Research, namely research that investigates or is testing or conducting experiments. A total of 3 articles or equal to $10 \%$ is a type of Evaluation Research, namely collecting relevant information to provide feedback. Quantitative research methods are methods that are carried out through measurement, calculation of formulas and numerical data (Musianto, 2002). This method is used as much as 29 articles or $87 \%$ of the total articles collected by the SMS method. Qualitative methods carried out by observation, data review, interviews, case 
studies, observations (Musianto, 2002) obtained 3 articles or only $9 \%$ of the total articles collected and the remaining 1 article using a mix method or a combination of both quantitative and qualitative.

Based on the results of mapping classified in 2015 - 2020, the results illustrated in the chart below are obtained.

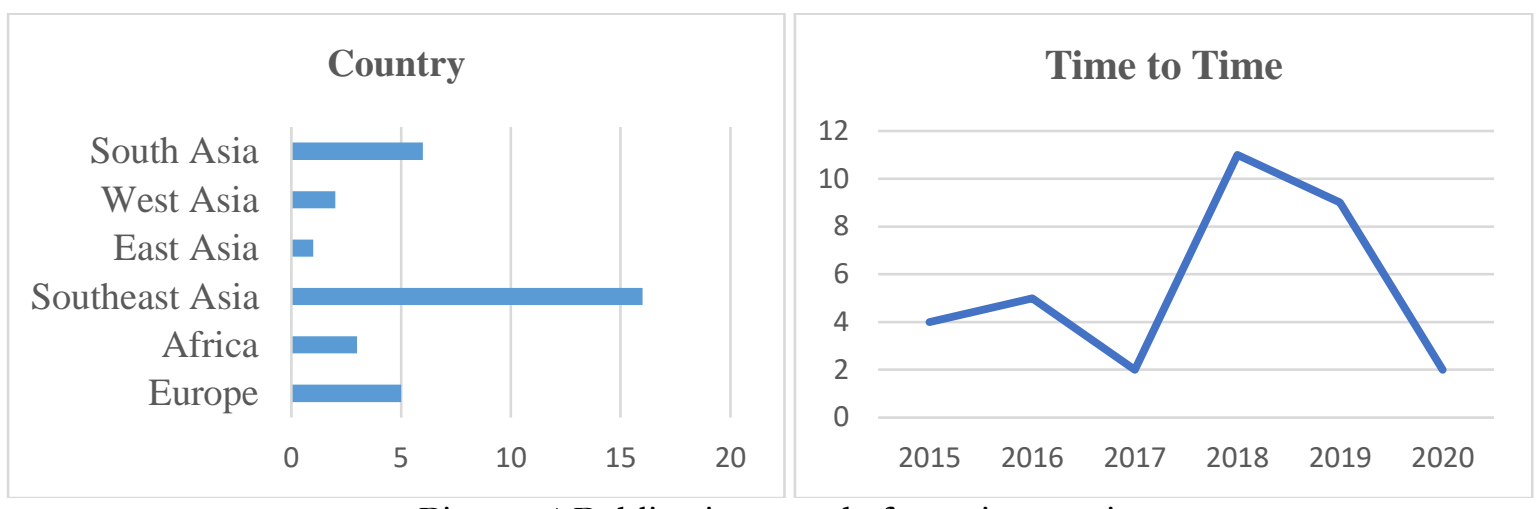

Picture 4 Publication trends from time to time

Source: Data Processed (2020)

Southeast Asia is the most research on halal food. Indonesia is the country with the most research on halal food, with 7 articles (21\%) followed by Malaysia with 6 articles (18\%). 2018 is the year when research on Consumer Behavior in Halal Food is most frequently published.

This research, which is rooted in the literature review, provides a comprehensive overview of Consumer behavior in Halal Food. The Systematic Mapping Study (SMS) was taken from the source database of research articles Emerald, Science Directs, Taylor \& Francis Online and ProQuest. There were 354 articles and only 251 articles that fit the topic of Consumer Behavior in Halal Food. After further analysis, only 33 articles met the inclusion criteria. It can be seen that the theme of purchase intention is the theme most researched, which is $18 \%$ of the total 33 articles collected. Food \& Beverage is also the locus most frequently researched, reaching $73 \%$ followed by raw meat at $18 \%$ and restaurant at $9 \% .90 \%$ of the articles were Validation Research with quantitative methods. However, there are 3 articles using qualitative methods and 1 article using the mix method. Southeast Asia, especially Indonesia, is a country with the largest number of Muslims in the world contributing the most research on consumer behavior in halal food and 2018 was the year with the most scientific publications in the same field. Mapping study based research can provide a comprehensive picture of a particular topic and can be used for further research. However, there is a weakness, this study only comes from several databases, namely Emerald, ScienceDirect, Taylor \& Francis Online and ProQuest and does not cover all existing databases and only takes a narrow period of time, 2016 to 2020. The database is also devoted to English-language research papers. and excludes scientific books, magazines, newspapers, annual reports.

\section{CONCLUSION}

The global halal market is very promising because the growth of Muslims in the world is very fast. Halal food has also become a consideration in the behavior of Muslim and non-Muslim consumers. Halal products, food, beverages, meat products, restaurants are defined as products that are clean, healthy and not contaminated and also practice animal slaughter in a better way. Although only taken from a limited database, this mapping study is very important for other researchers who are interested in the theme of Consumer Behavior in Halal Food because it can 
describe research trends that match the theme. This study maps themes about purchase intention, consumer perception, perceived value, awareness, willingness to pay, trust and impulse buying. This SMS method provides a broad understanding of consumer behavior in the halal context. This method can also provide an overview of the gaps for future research.

\section{REFERENCES}

Ab Talib, M. S., \& Ai Chin, T. (2018). Halal food standard implementation: are Malaysian firms proactive or reactive? British Food Journal, 120(6), 1330-1343. https://doi.org/10.1108/BFJ07-2017-0366

Ahmed, W., Najmi, A., Faizan, H. M., \& Ahmed, S. (2019). Consumer behaviour towards willingness to pay for Halal products: An assessment of demand for Halal certification in a Muslim country. British Food Journal, 121(2), 492-504. https://doi.org/10.1108/BFJ-02-20180085

Awan. (2015). Management Research Review For Authors. Management Research Review, 38(2). https://doi.org/10.1108/MRR-08-2013-0185

Ayyub, R. M. (2015). Exploring perceptions of non-Muslims towards Halal foods in UK. British Food Journal, 117(9), 2328-2343. https://doi.org/10.1108/BFJ-07-2014-0257

Banaeianjahromi, N., \& Smolander, K. (2016). What do we know about the role of enterprise architecture in enterprise integration? A systematic mapping study. Journal of Enterprise Information Management, 29(1), 140-164. https://doi.org/10.1108/JEIM-12-2014-0114

Bashir, A. M. (2019). Effect of halal awareness, halal logo and attitude on foreign consumers' purchase intention. British Food Journal, 121(9), 1998-2015. https://doi.org/10.1108/BFJ-012019-0011

Bonne, K., \& Verbeke, W. (2008). Muslim consumer trust in halal meat status and control in Belgium. Meat Science, 79(1), 113-123. https://doi.org/10.1016/j.meatsci.2007.08.007

Diallo, M. F. (2012). Effects of store image and store brand price-image on store brand purchase intention: Application to an emerging market. Journal of Retailing and Consumer Services, 19(3), 360-367. https://doi.org/10.1016/j.jretconser.2012.03.010

Dinar Standard, T. R. and. (2018). State of the Global Islamic Economy Report 2018/19. Dubai International Financial Centre, 112. https://haladinar.io/hdn/doc/report2018.pdf

Fauzi, A. H., Rizal, M., \& Arifianti, R. (2019). Corporate Entrepreneurship In SMEs : A Systematic Mapping Study. Jurnal Manajemen Pelayanan Publik, 2(1), 55. https://doi.org/10.24198/jmpp.v2i1.21575

Fischer, J. (2012). Branding halal. Anthropology Today, 28(4), 18-21.

Heredia, A., Colomo-Palacios, R., \& Amescua-Seco, A. (2015). A systematic mapping study on software process education. CEUR Workshop Proceedings, 1368(May), 7-17.

Khan, G., \& Khan, F. (2019). "Is this restaurant halal?" Surrogate indicators and Muslim behaviour. Journal of Islamic Marketing, 11(5), 1105-1123. https://doi.org/10.1108/JIMA-012019-0008

Kitchenham, B. (2004). Procedures for Performing Systematic Reviews Kitchenham, B., 2004. Keele, UK, Keele University, 33(2004), 1-26.

Kurniawan, D., \& Kunto, S. Y. (2013). Pengaruh Promosi Dan Store Atmosphere Terhadap Impulse Buying Dengan Shopping Emotion Sebagai Variabel Intervening Studi Kasus Di Matahari Department Store Cabang Supermall Surabaya. Jurnal Manajemen Pemasaran Petra, 1(2), 3 . 
Mahbubi, A., Uchiyama, T., \& Hatanaka, K. (2019). Capturing consumer value and clustering customer preferences in the Indonesian halal beef market. Meat Science, 156(April), 23-32. https://doi.org/10.1016/j.meatsci.2019.05.012

Marmaya, N. H., Zakaria, Z., \& Mohd Desa, M. N. (2019). Gen Y consumers' intention to purchase halal food in Malaysia: a PLS-SEM approach. Journal of Islamic Marketing, 10(3), 1003-1014. https://doi.org/10.1108/JIMA-08-2018-0136

Martin, C. R. A. (1971). British Food Journal. British Food Journal, 73(3), 65-96. https://doi.org/10.1108/eb011680

Musianto, L. S. (2002). Perbedaan Pendekatan Kuantitatif Dengan Pendekatan Kualitatif Dalam Metode Penelitian. Jurnal Manajemen Dan Wirausaha, 4(2), 123-136. https://doi.org/10.9744/jmk.4.2.pp.123-136

Muslichah, M., Abdullah, R., \& Abdul Razak, L. (2019). The effect of halal foods awareness on purchase decision with religiosity as a moderating variable: A study among university students in Brunei Darussalam. Journal of Islamic Marketing, 11(5), 1091-1104. https://doi.org/10.1108/JIMA-09-2017-0102

Petersen, K., Feldt, R., Mujtaba, S., \& Mattsson, M. (2008). Systematic mapping studies in software engineering. 12th International Conference on Evaluation and Assessment in Software Engineering, EASE 2008, February 2015. https://doi.org/10.14236/ewic/ease2008.8

Puiu, S., \& Budica, B. A. (2016). Universitatea din Craiova Silvia PUIU Universitatea din Craiova Bogdan Andrei BUDICA Universitatea din Craiova University of Craiova University of Craiova University of Craiova O definitie a comportamentului consumatorului este "Studiul indivizilor, sau. July 2015.

Rahman, M. S., Zaman, M. H., Hassan, H., \& Wei, C. C. (2018). Tourist's preferences in selection of local food: perception and behavior embedded model. Tourism Review, 73(1), 111-132. https://doi.org/10.1108/TR-04-2017-0079

Talib, M. S. A. (2015). Motivations and benefits of Halal food safety certification. Journal of Islamic Marketing, 8(4), 605-624.

Wertenbroch, K., \& Skiera, B. (2002). Measuring consumers' willingness to pay at the point of purchase. Journal of Marketing Research, 39(2), 228-241. https://doi.org/10.1509/jmkr.39.2.228.19086

Wieringa, R., Maiden, N., Mead, N., \& Rolland, C. (2006). Requirements engineering paper classification and evaluation criteria: A proposal and a discussion. Requirements Engineering, 11(1), 102-107. https://doi.org/10.1007/s00766-005-0021-6

Zeithaml, V. A. (1988). Consumer Perception of E-Service Quality.pdf. Jounal Of Marketing, 52(July), 22. 